\title{
PELATIHAN PENERAPAN BLENDED LEARNING MENGGUNAKAN METODE FLIPPED CLASSROOM DI MAN 1 KAMPAR PADA ERA NEW NORMAL
}

\author{
Molli Wahyuni ${ }^{1}$, Adityawarman Hidayat ${ }^{2}$, Zulhendri $^{3}$, Sriyani $^{4}$ \\ ${ }^{1,2,3,4)}$ Program Studi Matematika, Fakultas Ilmu Pendidikan, Universitas Pahlawan Tuanku Tambusai \\ e-mail: whykpr@gmail.com, adityawarmanhidayat@ymail.com, zulhendripoenya@gmail.com, \\ sriyani3101@gmail.com
}

\begin{abstract}
Abstrak
Pembelajaran di era new normal di masa pandemi Corona Virus Disease 2019 (COVID-19) menuntut guru untuk lebih inovatif dan kreatif dalam mempersiapkan pembelajaran. Kegiatan ini dilaksanakan dalam membantu para guru menyelenggarakan pendidikan new normal yang berkualitas sehingga tujuan pembelajaran tercapai sebagaimana mestinya. Pendekatan yang disampaikan adalah participatory action research (PAR) dengan mitra kegiatan di Madrasah Aliyah Negeri (MAN) 1 Kampar. Kegiatan dilaksanakan dalam tiga tahap, yaitu identifikasi masalah, pelaksanaan kegiatan dan evaluasi kegiatan. Kegiatan diikuti oleh 20 orang guru, dan materi yang diberikan antara lain berupa pelatihan pembuatan video pembelajaran menggunakan berbasis rekam layar menggunakan aplikasi Screencast O'matic dan pembelajaran blended learning menggunakan metode flipped classroom. Hasil kegiatan ini berupa kemampuan guru dalam membuat video pembelajaran berbasis rekam layar Screencast O'matic dan mempraktekkan pelaksanaan model flipped classroom yang tergambar pada saat simulasi setelah pelatihan dilaksanakan. Indikator keberhasilan pelaksanaan pengabdian kepada masyarakat ini adalah kegiatan terlaksana sesuai rencana, serta respon positif dari peserta.
\end{abstract}

Kata Kunci: Screen O'Matic, Blended Learning, Flipped Classroom, Covid19

\begin{abstract}
s
Learning in the new normal era during the Corona Virus Disease 2019 (COVID-19) pandemic era requires teachers to be more innovative and creative in preparing for learning. This activity is carried out in helping teachers to provide quality new normal education so that the learning objectives are achieved as they should. The approach presented is participatory action research (PAR) with activity partners at Madrasah Aliyah Negeri (MAN) 1 Kampar. The activity is carried out in three stages, namely problem identification, activity implementation and activity evaluation. The activity was attended by 20 teachers, and the material provided included training on making learning videos using screen recording based on the Screencast O'matic application and blended learning using the flipped classroom method. The result of this activity is the teacher's ability to make instructional videos based on the Screencast O'matic screen record and practice the implementation of the flipped classroom model that is depicted during the simulation after the training is carried out. The indicators of the success of this community service implementation are activities carried out according to plan, as well as positive responses from participants.
\end{abstract}

Keywords: Screen O’Matic, Blended Learning, Flipped Classroom, Covid19 


\section{PENDAHULUAN}

Madrasah Aliyah Negeri (MAN) I Kampar merupakan salah satu madrasah yang terkemuka di Kabupaten Kampar.Madrasah ini merupakan salah satu tumpuan masyarakat untuk menyekolahkan anak dengan kurikulum seimbang antara pelajaran umum dan agama Islam.Persoalan belajar dari rumah yang harus dilaksanakan saat ini dirasakan sangat mengubah pola pembelajaran di seluruh sekolah, tak terkecuali MAN 1 Kampar. Masa pandemi Covid-19 yang belum juga reda. Membuat MAN 1 Kampar juga harus mengikuti perpanjangan masa belajar dari rumah. Keterbatasan fisik untuk bertemu secara langsung antara guru dan peserta didik perlu diatasi dengan memanfaatkan perkembangan teknologi informasi, meskipun masih banyak kendala yang terjadi.

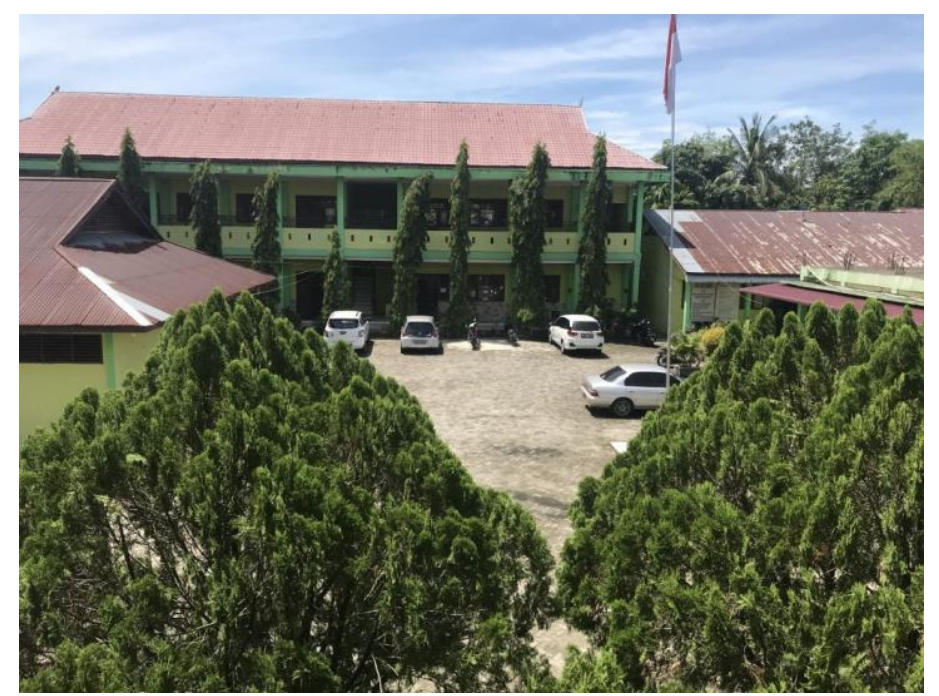

Gambar.1. Lingkungan Sekolah MAN 1 Kampar

Pelaksanaan belajar dari rumah yang berjalan saat ini dilaksanakan oleh guru MAN 1 Kampar umumnya menggunakan grup-grup di media sosial Whatsapp atau memanfaatkan fitur di kelas digital Google Classroom. Adanya grup di media sosial atau kelas digital, memudahkan guru dan peserta didik untuk saling berinteraksi. Biasanya pemberian materi dan tugas (LKS) memanfaatkan grup atau kelas digital tersebut. Pola pemberian materi pelajaran dan penugasan yang monoton seringkali membuat peserta didik merasa bosan dalam masa belajar dari rumah ini.

Salah satu model pembelajaran yang cukup relevan untuk diterapkan dalam rangka belajar dari rumah adalah model pembelajaran Flipped Classroom. Gagasan seputar pendekatan kelas terbalik untuk instruksi bukanlah hal baru dalam arti bahwa banyak pendidik telah bereksperimen dengan membalikkan peran penyampaian konten tradisional dengan peran praktik atau pekerjaan rumah. Banyak yang berpendapat bahwa definisi arus utama dari flipped classroom hanya "pengemasan ulang ide-ide lama" (Bergmann \& Sams, 2014). Bergmann dan Sams (2014), dua pelopor pendekatan kelas terbalik, setuju bahwa ide konten pra-pengajaran sangat cocok dengan strategi di sekitar kelas yang dibalik.

Pembelajaran terbalik juga telah didefinisikan oleh Flipped Learning Network sebagai, pendekatan pedagogis di mana instruksi langsung berpindah dari ruang belajar kelompok ke ruang belajar individu, dan ruang kelompok yang dihasilkan diubah menjadi lingkungan belajar yang dinamis dan interaktif di mana pendidik memandu siswa saat mereka menerapkan konsep dan terlibat secara kreatif dalam materi pelajaran (The Flipped Learning Network, 2014). Bergmann dan Sams (2012) membedakan antara istilah 'kelas terbalik' dan 'pembelajaran terbalik'.Flipped classroom tidak perlu mengarah pada Flipped Learning Network (FLN). Ada interpretasi yang berbeda dari pendekatan ini dan variasi terkait dalam strategi implementasi. Menurut Bergmann, Overmyer dan Wilie (2013) karakteristik flipped learning adalah: 
a. Peningkatan interaksi dan waktu kontak yang dipersonalisasi antara siswa dan guru;

b. Siswa bertanggung jawab atas pembelajaran mereka sendiri;

c. Peran guru bukanlah 'orang bijak di atas panggung', tetapi 'pemandu di samping';

d. Campuran instruksi langsung dengan pembelajaran konstruktivis;

e. Siswa yang tidak dapat menghadiri kelas karena sakit atau kegiatan ekstrakurikuler seperti atletik atau karyawisata, tidak ketinggalan;

f. Konten dicapai secara permanen untuk ditinjau atau diperbaiki;

g. Semua siswa terlibat dalam pembelajaran mereka;

h. Semua siswa dapat menerima pendidikan yang dipersonalisasi.

Abeysekera dan Dawson (2015, p. 3) mendefinisikan karakteristik tipikal dari ruang kelas terbalik atau flipped classroomdalam pengaturan pendidikan tinggi berikut:

a. Perubahan penggunaan waktu kelas;

b. Perubahan penggunaan waktu di luar kelas;

c. Melakukan kegiatan yang secara tradisional dianggap sebagai 'pekerjaan rumah' di kelas;

d. Melakukan kegiatan yang secara tradisional dianggap sebagai pekerjaan kelas di luar kelas;

e. Kegiatan di dalam kelas yang menekankan pada pembelajaran aktif, dan pemecahan masalah;

f. Kegiatan pra-kelas dan pasca-kelas;

g. Penggunaan teknologi, khususnya video;

Media video yang digunakan pada Flipped Classroom mempunyai karakteristik yang spesifik sehingga sering digunakan untuk media pembelajaran. Media video mempunyai kelebihan antara lain dapat menarik perhatian peserta didik meskipun dalam durasi yang singkat. Proses yang kompleks dari suatu pembelajaran dapat dipersiapkan sebelumnya oleh guru dan dapat direkam, sehingga pada saat pembelajaran di kelas guru dapat fokus untuk berdiskusi dengan peserta didik dan bertanya jawab untuk pendalaman materi.

Selama masa pandemic, para guru masih belum memahami bagaimana menerapkan model yang mendukung dalam kelancaran pembelajaran. Siswa dan orang tua juga merasakan ketidaknyamanan dalam proses pembelajaran yang bahkan dikatakan seperti "tidak belajar" karena terkesan dengan rutinitas pemberian tugas saja, dimana kedatangan ke sekolah hanya untuk mengantar tugas saja. Maka dari itu perlu diberikan pelatihan penerapan blended learning menggunakan model flipped classroom di MAN 1 Kampar

\section{METODE}

Dalam pelaksanaan kegiatan pengabdian ini, tim memanfaatkan fasilitas di labor komputer sekolah yang dilengkapi dengan fasilitas internet. Pengabdian dilaksanakan pada 2528 Februari 2021. Metode yang digunakan yakni metode pelatihan yang disesuaikan dengan kebutuhan dari sekolah mitra dengan melibatkan 20 orang guru. Kegiatan sebelum penerapan model blended learning, guru terlebih dahulu diberikan pembekalan tentang cara membuat video pembelajaran menggunakan aplikasi rekam layar screen omatic. Video tersebut digunakan sebagai penyajian materi untuk proses flipped classroom.

\section{HASIL DAN PEMBAHASAN}

Tim pelaksana pengabdian masyarakat Universitas Pahlawan Tuanku Tambusai melaksanakan kegiatan pengabdian masyarakat pada hakikatnya merupakan bentuk dukungan Universitas Pahlawan Tuanku Tambusai terhadap peningkatan kualitas pendidikan di masa pandemi covid19. Hasil kegiatan pengabdian kepada masyarakat ini dapat dilihat dalam kegiatan-kegiatan yang dilaksanakan tim kepada sekolah mitra sebagai berikut.

1. Pelatihan membuat video pembelajaran berbasis rekam layar.

Kegiatan ini merupakan tahapan yang perlu dilaksanakan untuk membimbing para guru membuat video pembelajaran rekam layar guna meningkatkan kemampuan guru dalam 
menyajikan materi pembelajaran di masa pandemi. Aplikasi video rekam layar yang digunakan adalah screencast o matic, sebagai salah satu aplikasi yang ringan dan mudah untuk dipelajari dan digunakan.

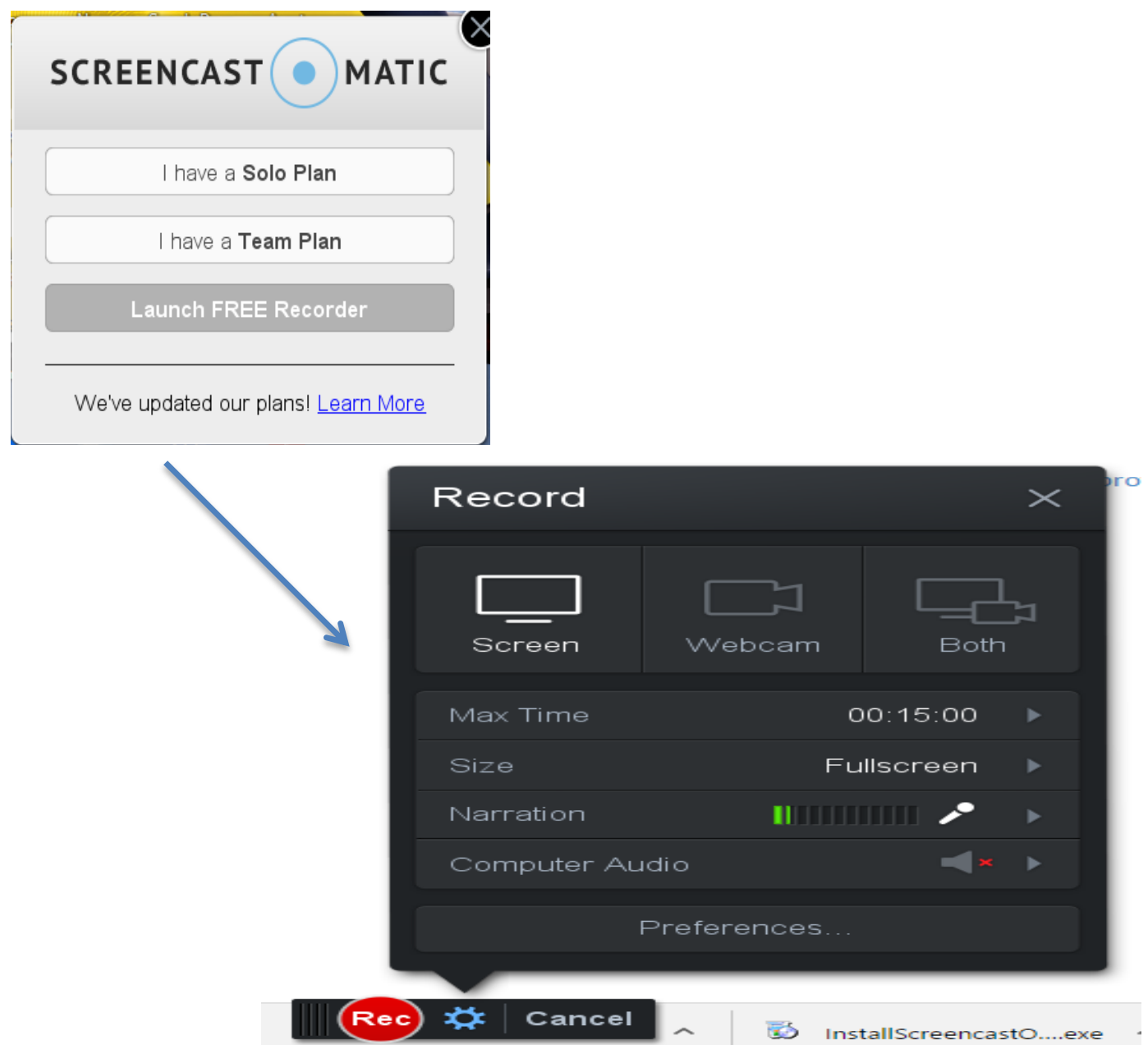

Gambar 2. Bentuk Aplikasi Screencast O'Matic

Para guru dilatih menggunakan aplikasi rekam layar ini, dengan merekam pemaparan power point materi pelajaran. Wajah guru terlihat langsung dalam video tersebut sehingga anak tetap merasakan hubungan komunikasi dengan guru mata pelajaran terkait, meski harus melalui video. Setiap guru menggunakan laptop yang lengkap dengan fasilitas internet untuk melakukan proses perekaman, dimana setiap video maksimal berdurasi 15 menit.
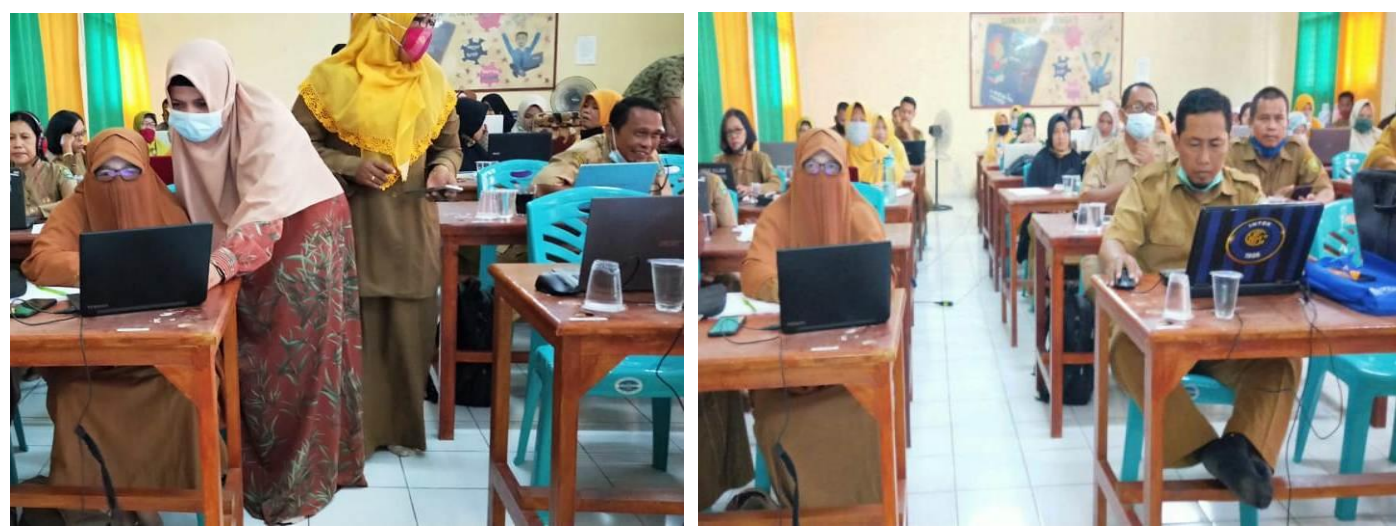

Gambar 3. Pelaksanaan Pelatihan 
Memberikan video hasil karya guru kepada siswa merupakan salah satu bentuk kreativitas guru dalam mengajar di masa pandemi ini. Video merupakan media yang sering digunakan sebagai input untuk belajar mandiri karena dapat diakses dan memungkinkan siswa untuk berhenti dan menonton kembali konten sesuai kebutuhan.

\section{Pelatihan Blended Learning}

Pelatihan blended learning diawali dengan penyajian materi tentang blended learning sebagai salah satu model pembelajaran yang dianjurkan pemerintah di masa pandemi ini. Metode yang digunakan adalah flipped classroom, karena waktu pertemuan siswa dengan guru di Semester Genap 2020/2021 sangat terbatas. Berikut ini salah satu ilustrasi dari pelaksanaan pembelajaran blended learning menggunakan metode flipped classroom:

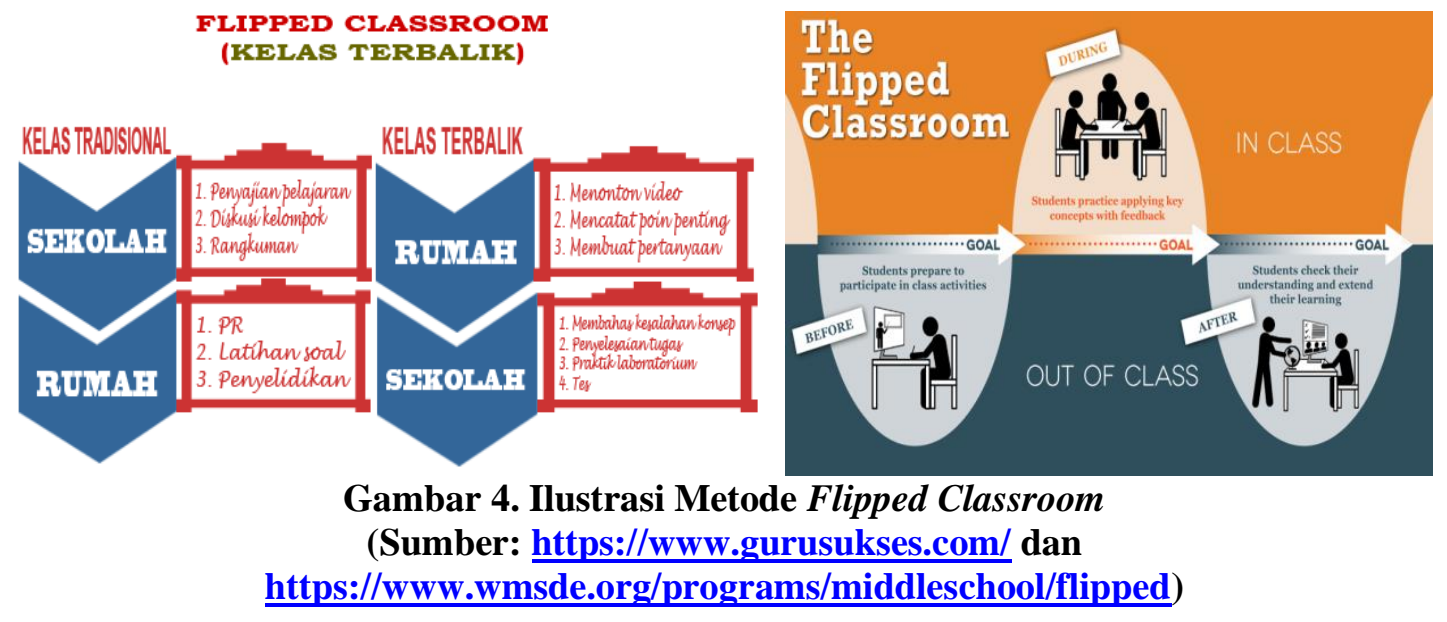

Kelas terbalik ini didefinisikan sebagai strategi pembelajaran yang menggantikan ceramah tradisional dengan video atau screencast yang tersedia untuk siswa di luar waktu kelas.Di kelas, pekerjaan kemudian dikhususkan untuk pengalaman yang lebih interaktif dan langsung (Bull, Ferster, \& Kjellstrom, 2012). Pengalaman belajar langsung atau aktif ini konsisten dengan prinsip konstruktivis karena mendukung proses di mana siswa membangun pemahaman sendiri berdasarkan pengetahuan yang ada dan pengalaman siswa (Bruner, 1960).

Pada pelatihan ini dilaksanakan simulasi pelaksanaan model blended learning menggunakan metode flipped classroom. Materi model pembelajaran blended learning menggunakan metode flipped classroom yang disampaikan kepada guru antara lain:

1. Kegiatan di Rumah

a. Guru secara langsung tampil synqronous selama 10 menit pertama (siswa mengikuti secara daring lengkap dengan atribut sekolah dari rumah masing-masing) dengan materi:

- Penjelasan singkat materi

- Langkah-langkah belajar

- Tagihan yang harus dicapai

- Rencana Evaluasi

b. Mengirimkan video pembelajaran sebelum pembelajaran daring dilaksanakan

- Siswa mencatat poin-poin penting dari materi yang disampaikan

- Siswa mencatat pertanyaan yang akan disampaikan pada tatap muka di sekolah

- Siswa mengerjakan tugas sesuai dengan modul

2. Kegiatan di Sekolah

c. Guru melakukan review materi yang disampaikan di video

d. Tanya jawab guru dan siswa

e. Guru melakukan pengecekan tugas dan memberikan evaluasi formatif dalam bentuk soal, kuis dan pertanyaan langsung. 
f. Guru mendiskusikan hasil evaluasi pembelajaran yang telah dilaksanakan dan memberikan informasi rencana pembelajaran berikutnya.

\section{SIMPULAN}

Berdasarkan pelaksanaan kegiatan pengabdian kepada masyarakat, tim pelaksana pengabdian dari Universitas Pahlawan Tuanku Tambusai menunjukkan capaian yang telah dilaksanakan, yakni (1) terlaksananya pelatihan pembuatan video pembelajaran berbasis rekam layar sebagai media yang akan digunakan untuk penerapan model pembelajaran blended learning dengan metode flipped classroom, dan (2) terlaksananya pelatihan penerapan model pembelajaran blended learning dengan metode flipped classroom di MAN 1 Kampar.

\section{SARAN}

Disarankan kepada pemerintah maupun pihak sekolah untuk meningkatkan pelatihanpelatihan bagi guru di masa pandemi guna mendorong kompetensi guru untuk menjadi lebih profesional dalam melaksanakan tugas.

\section{UCAPAN TERIMAKASIH}

Penulis mengucapkan terimakasih kepada Rektor Universitas Pahlawan Tuanku Tambusai yang telah memberikan dukungan moril dan materil untuk pelaksanaan pengabdian kepada masyarakat ini. Ucapan terimakasih juga kami sampaikan kepada Kepala MAN 1 Kampar dan jajaran serta para guru yang telah memberikan dukungan terlaksananya pengabdian kepada masyarakat ini.

\section{DAFTAR PUSTAKA}

Abeysekera, L., \& Dawson, P. (2015). Motivation and cognitive load in the flipped classroom: definition, rationale and a call for research. Higher Education Research and Development, 34(1), 1-14. https://doi.org/10.1080/07294360.2014.934336

Bergmann, J., \& Sams, A. (2014). Flipped learning: Gateway to student engagement. Learning \& Leading with Technology, May 2014, 18-23.

Berrett, D. (2012). How 'flipping' the classroom can improve the traditional lecture. The Chronicle of Higher Education, February 19, 2012. Overmyer, J. (2012). Flipped classrooms 101. Principal, September/October 2012, 4647.

Bramasta, Dandy Bayu. (2020). "Mengenal Apa Itu New Normal di Tengah Pandemi Corona...". Diakses tanggal 20 Mei 2020 dari https://www.kompas.com/tren/read/2020/05/20/063100865/mengenalapa-itu-new- normal-di- tengah-pandemi-corona-

Brian, A., and K.N. Volchenkova. (2016). Blended Learning: Definition, Models, Implication for Higher Education. Bulletin of the South Ural State University. Ser. Education. Educational Sciences. vol. 8, no. 2, pp. 24-30. Diaksesdari https://www.researchgate.net/publication/303815166_BLENDED_LEARNING_DEFINITIO N_MODELS_IMPLICATIONS_FOR_HIGHER_EDUCATION

Bruner, J. (1960). The process of education. Cambridge, MA: Harvard University Press.

Bull, G., Ferster, B., \& Kjellstrom, W. (2012). Inventing the flipped classroom. Learning \& Leading with Technology, 40.1, August 2012, 10-12.

Chaeruman, Uwes A. (2020). Tips Implementasi Flipped Learning. Materi disajikan dalam Webinar APSTPI 2020.

Chaeruman, Uwes A. dan Santi Maudiarti. (2018). Quadrant of Blended Learning: a Proposed Conceptual Model for Designing Effective Blended Learning. Jurnal Pembelajaran Inovatifl(1) (2018): 1-5.Diakses pada tanggal 24 Mei 2020 dari http://journal.unj.ac.id/unj/index.php/jpi/article/view/5924/4373

Dziubal, Charles., et.al. (2018). Blended learning: the new normal and emerging technologies. International Journal of Educational Technology in Higher Education volume 15, Article number: 3. Diakses pada tanggal 24 Mei 2020 dari 


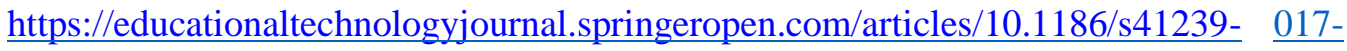
0087-5

Graham, Charles R. (2006). “ Blended Learning Systems: Definition, Current Trends, and Future Directions" dalam Bonk, J. Curtis dan Charles R. Graham (ed.). The Handbook of Blended Learning: Global Perspectives, Local Designs (pp. 3-21). Diakses dari https://books.google.co.id/books?id=2u2TxK06PwUC\&printsec=frontcover\&source $=\mathrm{gb} \mathrm{s}$ ge summary $\mathrm{r} \& \mathrm{cad}=0 \# \mathrm{v}=$ onepage $\& \mathrm{q} \& \mathrm{f}=$ false

Lembaga Penjaminan Mutu Pendidikan Lampung. (2020). Laporan Evaluasi Pelaksanaan Belajar dari Rumah. Tidak diterbitkan.

Soler, Rebeca., Juan Ramon Soler, Isabel Araya. (2017). Subjects in The Blended Learning Model Design. Theoretical Methodological Elements. Journal Social and Behavioral Sciences, 237, 2017, (771-777). Diakses dari

https://www.sciencedirect.com/science/article/pii/S1877042817301209

Thorne, K. (2003). Blended Learning: How to Integrate Online and Traditional Learning. London, UK: Kogan Page Limited.

Yuniarto, Eko. (2015). Penerapan Evaluasi pada Blended Learning Berbasis Moodle dalam Pembelajaran Kimia di Perguruan Tinggi. Jurnal Likhitaprajna, 17(2), 65-85. Diakses dari

http://likhitapradnya.wisnuwardhana.ac.id/index.php/likhitapradnya/article/view/17 